\title{
Chapter 9 \\ Southern Pennine Basin Margin: West Midlands to Vale of Belvoir
}

\author{
J.H. POWELL, C.N.WATERS, N.S. JONES \& C.J. CLEAL
}

The disparate coalfields and Carboniferous rocks in this area (Fig. 9.1; Fig. 9.2), mostly comprise coal measure lithofacies (Pennine Coal Measures Group) and red-bed sediments (Warwickshire Group) deposited at the southern margin of the Pennine Basin, which was initiated in Westphalian times. These strata generally rest unconformably on Lower Palaeozoic rocks in the west of the region, with local development of platform carbonates in Shropshire. The more extensive carbonate platform of the Hathern Shelf and coeval basinal mudstones (associated with the south-east trending Widmerpool Gulf) were deposited in the east of the region during late Tournaisian and Visean time. The basinal hemipelagic sedimentation continued in the southeast throughout the early Namurian with an influx of southerly derived quartzitic sandstone followed, in the Marsdenian, by northerly derived feldspathic sandstone (Millstone Grit Group) (Fraser \& Gawthorpe 2003)

The oldest Carboniferous strata of late Tournaisian to Visean age do not crop out widely in the region, but are known from boreholes and geophysical records in South Derbyshire and the Vale of Belvoir, and from small inliers in Shropshire and the Clee Hills. Platform carbonates with thin beds of basic tuffite and subordinate sandstone (Peak Limestone Group) were deposited on the Hathern Shelf at the southern margin of the Widmerpool Gulf (half-graben) (Falcon \& Kent 1960), but deepening of the basin through synsedimentary rift faulting and a rise in sea-level resulted in the deposition of deeper water calcareous mud (Widmerpool Formation) (Fraser \& Gawthorpe 2003). Most of the platform carbonate rocks in the region were deposited to the north of the WalesBrabant High, although Tournaisian strata in the Clee Hills and Little Wenlock areas of Shropshire probably represent strata of the Avon and Pembroke Limestone groups, a northward extension of the platform succession of South Wales (Mitchell \& Reynolds 1981; see Chapter 5).

During the Namurian, deeper water hemipelagic muds and carbonate-rich tubidites of the Bowland Shale Formation (Craven Group) were deposited in the southern part of the Widmerpool Gulf that extended to the area of the South Derbyshire Coalfield. Uplift of the hinterland (Wales-Brabant High) to the south resulted in an influx of quartz-rich sand (Morridge Formation) coeval with deposition of more basinal hemipelagic mud to the north. Subsequent influx of feldspathic sand derived from north of the Pennine Basin, deposited by major river and delta systems, resulted in widespread deposition of fluvio-deltaic deposits (Millstone Grit Group) which extended southwards to the Warwickshire area and Widmerpool Gulf by late Namurian times.

The overlying Westphalian strata (Pennine Coal Measures Group) are dominated by upper delta plain, fluvio-lacustrine deposits and palaeosols (coal, seatearth and fireclay) (Guion et al. 1995). Reddened coal measure lithofacies have been proved locally in the lower part of the group in the South Staffordshire (Whitehead \& Eastwood 1927; Powell et al. 2000a) and Forest of Wyre coalfields (Whitehead \& Pocock 1947), reflecting development of well drained alluvial conditions close to the southern margin of the Pennine Basin in early Langsettian times. This is followed by deposition, during the late Westphalian to Stephanian, of predominantly red-bed alluvial deposits with subordinate coal measure lithofacies (Warwickshire Group) (Besly 1988; Besly \& Fielding 1989). At the southern margin of the Pennine Basin, the Warwickshire Group onlaps to rest unconformably on Lower Palaeozoic rocks that represent the northern margin of the Wales-Brabant High. The Pennine Coal Measures and Warwickshire groups were deposited widely across the region, but the current preservation in disparate small coalfields (Figure 9.1) is a result of subsequent Variscan inversion tectonics. 
The lithostratigraphical nomenclature for the Carboniferous strata of the region is that of Waters et al. (2009).

\section{Tournaisian}

Carbonate and siliciclastic strata of Tournaisian age outcrop in a faulted inlier at Little Wenlock (Fig. 9.2, Col. 2). At the base, the Village Farm Formation (Bridge \& Hough 2002) comprises alluvial sandstone, breccia and conglomerate. There are no biostratigraphical data for the succession proved in boreholes in the Lilleshall area, but a late Devonian to Tournaisian age is proposed (Riley 1998). The Jackie Parr Limestone Formation (Bridge \& Hough 2002), which consists of limestone, pebbly sandstone and claystone was deposited in a shallow marine to intertidal/supratidal environment, representing the northernmost extent of the South Wales and Bristol shelf seas (Mitchell \& Reynolds 1981). The formation, which is interpreted as part of the Avon Group (Waters et al. 2009) includes conodonts which indicate the Siphonodella Zone and macrofossils representative of the Vaughnia vetus Zone, suggesting an early Tournaisian age ${ }^{\text {O*1 }}$ (Mitchell \& Reynolds 1981).

In the Clee Hills area (Fig. 9.2, Col. 3), a thin basal conglomerate is overlain by calcareous mudstone and limestone of the Avon Group (Waters et al. 2007) and succeeding crinoidal and ooidal limestones of Oreton Formation (George et al. 1976), interpreted by Waters et al. (2009) as the northernmost development of the Pembroke Limestone Group. Both groups have yielded miospores of Tournaisian (PC Zone) age ${ }^{\wedge}$ (Turner \& Spinner 1988).

The Hathern Anhydrite Formation, proved on the Hathern Shelf within the Hathern Borehole [SK 5158 2416] (Fig 9.2, Col. 9), includes miospore assemblages indicative of the CM Zone (Llewellyn et al. 1969). The overlying Milldale Limestone Formation includes foraminifers of the Cf4 $\alpha 1$ Subzone and the ammonoid Fascipericyclus fasiculatus indicating a late Tournaisian age ${ }^{\mathrm{O}+2}$ (N. J. Riley in Carney et al. 2001). In the Widmerpool Trough, strata of equivalent age are represented by the comparatively deeper water deposits of the Long Eaton Formation (Fig. 9.2, Col. 10), with the lowest $667 \mathrm{~m}$ part of the formation in the Long Eaton Borehole [SK 46403166 ] including foraminifers suggesting a late Tournaisian age ${ }^{\text {O1 }}$ (Riley 1997a).

\section{Visean}

Along the southern margin of the Hathern Shelf and the South Derbyshire Coalfield, Visean strata rest unconformably on Cambrian rocks (Fig 9.2, Col. 8). The siliciclastic succession present above this unconformity is proved only in the subsurface. The Ticknall Borehole [SK 5158 2416] proved the Calke Abbey Sandstone Formation, mainly alluvial fan deposits, overlain by the Arch Farm Sandstone Formation, representing a basal flooding surface passing up into fluvial deposition (Ambrose \& Carney 1997). The former is barren of fossils and the latter contains Lingula, so their respective ages have not been determined, but they have been attributed to the Holkerian-Asbian substages (Carney et al. 2001). The overlying dolostone and limestone platform carbonate succession is included in the Peak Limestone Group. The Cloud Hill Dolostone Formation, present in the Ticknall Borehole, includes early Asbian foraminifers Pojarkovella nibelis and Dainella holkeriana and Asbian miospores, about $5 \mathrm{~m}$ above the base of the formation ${ }^{\mathrm{O}^{\wedge}}$ (Riley 1997). The overlying Ticknall Limestone Formation contains foraminiferal assemblages consistent with a Brigantian age ${ }^{\mathrm{O} 2}$ (Riley 1997). At Cloud Hill Quarry [SK 413 215] the base of the Cloud Hill Dolostone Formation has yielded late Holkerian to early Asbian palynomorphs ${ }^{\wedge}$ (Fig. 9.2, Col. 9; Turner 1996). The Peak Limestone Group includes local disconformities at the base of the Ticknall Limestone (Fig. 9.2, Col. 8) and Cloud Hill Dolostone (Col. 9) formations. 
In the Little Wenlock inlier (Fig 9.2, Col. 2) the dominantly fluvial succession of the Lydebrook Sandstone Formation (Whitehead et al. 1928; Pocock et al. 1938; Hamblin \& Copack 1995) rests unconformably on Tournaisian limestone and onlaps on to Lower Palaeozoic rocks. Bivalve and brachiopod faunas indicate an Asbian ( $\mathrm{D}_{1}$ Subzone) age ${ }^{* 2}$ (Bracewell 1925), although palynological evidence (Turner et al. 1995) suggests an Asbian to early Brigantian age. The succeeding platform carbonate rocks, represented by the Sylvan Limestone Formation (Bridge \& Hough 2002) includes the extrusive, and occasionally submarine Little Wenlock Basalt Member. The presence of the brachiopod Davidsonina septosa within limestone below the basalt suggests an Asbian age ${ }^{* 3}$, but the upper limestone includes a shelly fauna of Brigantian age ${ }^{* 4}\left(\mathrm{D}_{2}\right.$ Zone $)$ (Pocock et al. 1938).

In the Widmerpool Gulf, the Visean succession is dominated by deep-water carbonate turbidites and hemipelagic mudstone of the Craven Group. There is an absence of proved late Chadian and Arundian strata within the Long Eaton Formation of the Long Eaton Borehole (Riley 1997a), suggesting a depositional hiatus (Fig. 9.2, Col. 10). The upper part of the formation includes foraminifers typical of the Holkerian Substage ${ }^{\mathrm{O} 2}$, though the topmost part may be of Asbian age (Riley 1997a). The overlying Lockington Limestone Formation comprises turbiditic limestone with mudstone interbeds. The first downhole appearance of abundant calcareous algae Koninckopora ${ }^{\mathrm{O} 3}$ (Riley 1997a) $85 \mathrm{~m}$ above the base of the formation indicates that the Asbian/Brigantian boundary occurs within the middle part of the formation. The Widmerpool Formation was deposited over a wide area of the southern part of the Widmerpool Gulf (Fig. 9.2, Col. 10) and as a condensed succession on the Hathern Shelf (Col. 8) during sea-level high stands. The formation comprises mainly calcareous mudstone, with subordinate beds of turbiditic argillaceous limestone and sandstone. Although the base of the formation within parts of the Widmerpool Gulf is thought to be late Asbian in age (Carney et al. 2004) it probably youngs diachronously toward the southern margin of the half-graben and is mostly Brigantian in age. Tuffs are common within the formation, with the Ratcliffe Volcanic Member identified in the Ratcliffe-on-Soar Borehole [SK 5081 2913] (Fig. 9.2, Col. 10) comprising 5 tuff beds intercalated with mudstone (Carney et al. 2001). Marine sedimentation did not extend westward of the present-day Warwickshire coalfield.

\section{Namurian}

Namurian rocks are mainly not present in the areas to the west of the region (west Warwickshire; South Staffordshire, Coalbrookdale, Wyre Forest, and Shrewsbury) where the Pennine Coal Measures and Warwickshire groups overlap onto Lower Palaeozoic rocks (Pocock et al. 1938; Whitehead \& Pocock 1947; Powell et al. 2000b). However, in the Clee Hills area (Fig. 9.2, Col. 3) conglomerate and pebbly quartzitic sandstone of the Cornbrook Sandstone Formation (E. E. L. Dixon, in Kidston et al. 1917; Greig et al. 1968) rest unconformably upon Devonian and Tournaisian strata. Miospore and macro-plant fossil age determinations are inconclusive, ranging from Namurian to Duckmantian (Jones and Owen 1961; B. Owens in Greig et al. 1968; Cleal \& Thomas, 1996) but the general consensus is that the Cornbrook Sandstone Formation is Pendleian to Arnsbergian in age ${ }^{\wedge}$ (Turner \& Owens 1993). This is slightly older than the Morridge Formation of South Derbyshire (Fig. 9.2, Col. 7) and of comparable age to the Cefn-y-fedw Sandstone Formation of North Wales (see Chapter 8), and may represent the southern extension of these formations into an embayment of the Wales-Brabant High (Waters et al. 2009).

In the east of the region, the Cravenoceras leion $\left(\mathrm{E}_{1 \mathrm{a}} 1\right)$ Marine Band marks a transition from the late Visean calcareous mudstone and carbonate turbidites of the Widmerpool Formation to the Namurian hemipelagic mudstone-dominated Bowland Shale Formation (formerly Edale Shale Group). During the early Pendleian, deposition of the Bowland Shale Formation extended 
southeastwards to the Widmerpool Gulf, represented by the successions in Vale of Belvoir (Fig. 9.2, Col. 10). In South Derbyshire the hemipelagic mudstone interfingers with quartzitic sandstone of the Morridge Formation (Arnsbergian to Marsdenian age), derived from the Wales-Brabant High to the south. The high proportion of quartz sand of southerly provenance (Trewin \& Holdsworth 1973) contrasts markedly with the influx of feldspathic sands of northerly provenance more typically associated with the Millstone Grit Group and which enter the area during the Kinderscoutian (Fig. 9.2, Col. 10) and Marsdenian (Cols. 5, 6 \& 7).

In the Vale of Belvoir (Fig. 9.2, Col. 10), the Namurian strata onlap and thin southwards across the margin of the Widmerpool Gulf on to the Hathern Shelf. The Widmerpool No.1 Borehole [SK 6366 2958] (Carney et al. 2004) proved mudstone with subordinate thin beds of sandstone and argillaceous limestone, of presumed Pendleian to Alportian age, attributed to the Bowland Shale Formation, overlying conformably the Brigantian Widmerpool Formation. Ammonoids indicative of the $\mathrm{E}_{1 \mathrm{a}}{ }^{+4}$ and $\mathrm{E}_{1 \mathrm{c}}{ }^{+5}$ zones are proved in the borehole. On the Hathern Shelf (Fig. 9.2, Col. 7) the ammonoid Eumorphoceras ferrimontanum $\left(\mathrm{E}_{2 \mathrm{a}} 2\right)^{+2}$ was proved within calcareous mudstone of the Bowland Shale Formation in the Ashby G1 borehole [SK 3134 2524] (Carney et al. 2001). These basinal lithofacies thin to the south, and are overlapped by the Morridge Formation.

In the Worthington Borehole of south Derbyshire [SK 4047 2104] (Fig. 9.2, Col. 7) the Bowland Shale Formation is absent, removed beneath the unconformity below the base of the Morridge Formation (Carney et al. 2001). In this borehole, the Morridge Formation comprises striped turbiditic mudstone, siltstone and quartzitic sandstone and includes marine bands $\mathrm{E}_{2 \mathrm{~b}-\mathrm{c}}{ }^{+2}, \mathrm{R}_{2 \mathrm{a}} 1^{+3}$, $\mathrm{R}_{2 \mathrm{~b}} 1^{+4}$, and $\mathrm{R}_{2 \mathrm{~b}} 5^{+5}$ (Carney et al. 2001). In the Vale of Belvoir (Fig. 9.2, Col. 10), sandstone possibly attributable to the Morridge Formation rests unconformably upon the Bowland Shale Formation. A Kinderscoutian age is indicated by the presence of the Reticuloceras coreticulatum $\left(\mathrm{R}_{1 \mathrm{c}} 4\right)$ Marine Band ${ }^{+6}$ found in mudstone intercalated with these sandstones (Carney et al. 2004). The typically quartzitic sandstone is characterised by a southerly provenance (Hallsworth 2000), but have higher feldspar contents than the typical Morridge Formation of north Staffordshire (see Chapter 10).

Influx of units of fluvio-deltaic coarse-grained sandstone derived from the north did not occur until the late Marsdenian (Hallsworth 2000); the coarse-grained sandstone of the Marsden Formation are correlated with the Ashover Grit and Chatsworth Grit further north. In the Vale of Belvoir (Fig. 9.2, Col. 10) intercalated mudstones yield Bilinguites superbilinguis $\left(\mathrm{R}_{2 \mathrm{c}} 1\right)^{+7}$ and the Verneulites sigma $\left(\mathrm{R}_{2 \mathrm{c}} 2\right)$ marine bands (Carney et al. 2004). In the South Derbyshire/Leicestershire coalfields (Fig. 9.2, Col. 7) the Bowland Shale Formation and Millstone Grit Group were proved in a number of boreholes (Worssam \& Old 1988). The Millstone Grit Group thins markedly to the south, but the northernmost boreholes proved the latest three substages of the Namurian, with the Kinderscoutian resting unconformably on the Brigantian Widmerpool Formation (Worssam \& Old 1988). Millstone Grit lithofacies overlap the basinal Bowland Shale Formation on to the Hathern Shelf at the southern part of the coalfield; key marine bands have been recognised in the Rotherwood Borehole and Ellistown Colliery Borehole, indicating Marsdenian (B. gracilis ${ }^{+6} \&$ B. superbilinguis ${ }^{+7}$ marine bands) and Yeadonian (Cancelloceras cancellatum Marine Band ${ }^{+8}$ ) substages (Worssam \& Old 1988).

In the east Warwickshire area (Fig. 9.2, Col. 6) the Millstone Grit delta and fluvial successions rest unconformably on Lower Palaeozoic rocks (Taylor \& Rushton 1971; Fulton \& Williams 1988; Bridge et al. 1998). Here, the B. superbilinguis $\left(\mathrm{R}_{2 \mathrm{c}} 1\right)^{+1}$ and $C$. cumbriense $\left(\mathrm{G}_{1 \mathrm{~b}} 1\right)^{+2}$ marine bands were tentatively identified by Ramsbottom (in Taylor \& Rushton 1971) in the Merevale No. 2 borehole [SP 3001 9509]. In the Whittington Heath Borehole [SK 1478 0800], near Lichfield, a 60 
$\mathrm{m}$ thick upper Kinderscoutian to Yeadonian succession unconformably overlies Early Carboniferous limestone that is less than $1 \mathrm{~m}$ thick (W. H. C. Ramsbottom, in Taylor \& Rushton 1971).

The Rossendale Formation is marked by a distinctive lower mudstone-dominated succession with the C. cancellatum and C. cumbriense marine bands, overlain by the sandstone-dominated Rough Rock, which marks the southward spread of northerly derived fluvio-deltaic lithofacies in Yeadonian times. To the northeast of the Cannock Coalfield (Fig. 9.2, Col. 5), Millstone Grit of Yeadonian age was proved by the presence of Cancelloceras cancellatum $\left(\mathrm{G}_{1 \mathrm{a}} 1\right)^{+1}$ and $\mathrm{C}$. cumbriense $\left(\mathrm{G}_{1 \mathrm{~b}} 1\right)^{+2}$ marine bands in the Rugeley Borehole [SK 0508 1902] (Stevenson \& Mitchell 1955). At outcrop on the west side of the Warwickshire Coalfield, Millstone Grit Group strata of Yeadonain age overlie Cambrian rocks unconformably at Dosthill, near Tamworth (Taylor \& Rushton 1971).

Crustal extension, probably related to faulting along the basin margin, resulted in the coeval subaqueous and subaerial eruption of peperitic basaltic breccia with lenses of basalt (Asfordby Volcanic Formation) from Marsdenian times onwards (Fig. 9.2, Col. 10) - a precursor to extensive volcanic activity in the early Westphalian (Burgess 1982; Carney et al. 2004).

\section{Westphalian}

The Pennine Coal Measures Group consists of a grey, mudstone-dominated succession that was deposited in lower to upper delta plain environments (Guion \& Fielding 1988; Guion et al. 1995) throughout the region during Langsettian to early Bolsovian times. Diachronous passage to alluvial red-bed lithofacies (Etruria Formation) was initiated in early to mid Bolsovian time near the southern margin of the Pennine Basin, and this change was accompanied by an influx of coarsegrained siliciclastic sediment derived from the uplifted hinterland to the south and west (Besly 1988; Glover \& Powell 1996; Glover et al. 1996). Local reddening of the upper delta plain sediment also occurred at the southern (South Staffordshire) and western (Shrewsbury) margins of the basin in early Langsettian times (Powell et al. 2000a). Coeval volcanic rocks and associated intrusions are present in the Langsettian strata (the Saltby Volcanic and Ashfordby Volcanic formations) of the Vale of Belvoir coalfield (Burgess 1982; Carney et al. 2004), a continuation of volcanicity initiated during the Marsdenian, and in South Staffordshire during the Bolsovian (Glover et al. 1993).

The thickest development of Westphalian strata in this region is in the South Derbyshire Coalfield (Fig. 9.2, Col. 7; Fig. 9.3b), where post-rift basinal subsidence was greatest (Fraser \& Gawthorpe 2003). The succession thins southwards, especially in the South Staffordshire (Fig. 9.2, Col. 5; Fig. 9.3a) and Wyre Forest (Fig. 9.2, Col. 5; Fig. 9.3a) coalfields, located close to the southern basin margin. In the south and west of the region, the Pennine Coal Measures Group laps on to Lower Palaeozoic rocks (South Staffordshire, Wyre Forest and Coalbrookdale) but at Titterstone Clee (Fig. 9.2, Col. 3) the group locally rests unconformably on the Namurian strata (Greig et al. 1968) and miospores indicate a Langsettian to lower Duckmatian age ${ }^{\wedge}$ (Turner \& Spinner 1990). Reduced rates of subsidence and prolific plant growth near the southern margin of the basin are manifested in the development of amalgamated coal seams such as the Thick Coal (up to $17 \mathrm{~m}$ thick) of the Staffordshire and Warwickshire coalfields (Powell et al. 2000a; Bridge et al. 1998).

The base of the Pennine Lower Coal Measures is taken regionally at the base of the Subcrenatum Marine Band. However, as a result of local reddening in basin margin settings, this marker bed is present only in the north-east of Coalbrookdale Coalfield (Fig. 9.2, Col. $2^{+1}$; Fig. 9.3a; Hamblin \& 
Coppack 1995), the north of the Cannock Chase Coalfield (Fig. 9.3a; Stubblefield \& Calver in Stevenson \& Mitchell 1955), the north of the South Derbyshire Coalfield (Fig. 9.2, Col. ${ }^{+9}$; Fig. 9.3b; Worssam \& Old 1988), the Vale of Belvoir (Fig. 9.2, Col.10 ${ }^{+8}$; Fig. 3b; Carney et al. 2004) and as a Lingula Band in the Merevale No. 2 Borehole in the Warwickshire Coalfield (Fig. 9.3b; Taylor \& Rushton 1971; Bridge et al. 1998). In the east of the region, the lower part of the formation below the Kilburn Coal is dominated by thin coals and common marine bands, most numerous in the Vale of Belvoir (Fig. 9.3b). In the west of the region, only the Listeri and Amaliae marine bands are evident within the formation above the Subcrenatum Marine Band in Coalbrookdale and South Staffordshire coalfields (Fig. 9.3a). The upper part of the formation is dominated by thicker and laterally persistent coals and locally thick development of seatearth palaeosols.

The Vanderbeckei Marine Band, which marks the base of the Pennine Middle Coal Measures Formation, is present throughout most of the region with a fully marine fauna including the definitive ammonoid identified in a number of boreholes in Coalbrookdale (Fig. 9.2, Col. $2^{+2}$; Fig. 9.3a; Hamblin \& Coppack 1995), South Staffordshire (Fig. 9.2, Col. $5^{+3}$; Fig. 9.3a; Whitehead \& Eastwood 1927), Warwickshire (Fig. 9.2, Col. $6^{+3}$; Fig. 9.3b; Bridge et al. 1998), South Derbyshire (Fig. 9.2, Col. $7^{+10}$; Fig. 9.3b; Worssam \& Old 1988), and the Vale of Belvoir (Fig. 9.2, Col. $10^{+9}$; Fig. 9.3b; Carney et al. 2004). In the marginal setting of the Wyre Forest, the marine band has not been proved, with strata at this level being locally reddened (Pocock et al. 1938). Thick coals seams are developed within this formation, with complex splitting of seams towards the north of the region. The Pennine Middle Coal Measures in this region have yielded macrofloras of similar diversity to those found in the Craven Basin (Cleal 2008d), with a notable peak in the middle Duckmantian Substage that can be correlated with a similar peak at the level of the Barnsley Main Seam in Yorkshire. In South Staffordshire, this peak occurs at the Coseley Ironstone, which has yielded an exceptionally-preserved biota in siderite nodules (Kidston 1914).

The level of the Aegiranum Marine Band is typically either absent or evidenced by the presence of Lingula or productids, with diagnostic fauna recorded in the Wyre Forest ${ }^{+1}$ (Fig. 9.2, Col. 4; Whitehead \& Pocock 1947) and South Derbyshire ${ }^{+11}$ (Fig. 9.2, Col. 7; Worssam \& Old 1988) coalfields. In the latter, strata between the Aegiranum Marine Band and the base the overlying Etruria Formation are relatively condensed (Fig. 9.3b) and have a higher proportion of seatearth fireclays (Pottery Clays) compared with the Nottinghamshire Coalfield (see Chapter 10) located to the north (Mitchell \& Stubblefield 1948; Worsam \& Old 1988).

The base of the Pennine Upper Coal Measures is regionally taken at the base of the Cambriense Marine Band, above which a thin succession of Coal Measures lithofacies are present in South Derbyshire (Fig. 9.2, Col. 7; Fig. 9.3b), and the northern parts of the South Staffordshire (Fig. 9.2, Col. 5; Fig. 9.3a) and Warwickshire (Fig. 9.2, Col. 6; Fig. 9.3b) coalfields. However, over much of the southern Pennine Basin margin, this marine band has not been recognised as a result of the diachronous passage to well drained alluvial red-bed lithofacies represented by the Etruria Formation (formerly Old Hill Marl, Hadley, Kinlet and Ruabon formations in the isolated coalfields).

The lateral, coeval passage to alluvial red-beds was accompanied by an influx of lenticular beds of pebbly coarser grained sandstone and conglomerate (locally known as 'espleys' with both exotic volcanic and lithic clasts). Alluvial red-bed conditions were initiated earlier in the south and west of the region (Coalbrookdale, Wyre Forest, South Staffordshire and Warwickshire; Fig. 9.3a \& b) at about the level of the Aegiranum Marine Band. However, in the south of these coalfields this marine band is absent with red-beds locally developed during the Duckmantian. In the west of the 
region, the Pennine Coal Measures are absent and the Etruria Formation rests unconformably on Lower Palaeozoic rocks (Fig. 9.2, Col. 1). Limited macrofloral evidence from South Staffordshire (Fig. 9.2, Col. 5) suggests the Etruria Formation here may not extend up into the upper Bolsovian Substage $^{\wedge}$ (Cleal 2008). In the Coalbrookdale Coalfield (Fig. 9.2, Col. 2), local uplift and erosion during Bolsovian times resulted in an unconformity (known locally as the Symon Unconformity) so that the Etruria Formation oversteps Pennine Middle Coal Measures in the south-southeast, but is conformable to the north-northwest (Hamblin \& Coppack 1995). The Etruria Formation varies greatly in thickness over the region due partly to the diachronous nature of the primary red-beds, and as a result of a widespread, but low-angle unconformity at the base of the overlying Halesowen Formation. Local volcanic activity in the south of the region in Bolsovian times resulted in the extrusion of volcaniclastic tuff and associated dolerite dykes and other intrusive rocks near Barrow Hill (Glover et al. 1993); rapid burial preserved early conifer plants (Galtier et al. 1992).

The Halesowen Formation (formerly Highley, Coalport and Coed-yr-Allt formations) is mainly Asturian (Westphalian D) in age (Waters et al. 1995 and references therein) but the basal Main Sulphur Coal at Coalbrookdale (Fig. 9.2, Col. 2; Fig. 9.3a) contains miospore assemblages including Vestispora costata that may be late Bolsovian in age ${ }^{\wedge}$ (Hamblin \& Coppack 1995). Microflora indicate an early Asturian age in the Dost Hill area of the Warwickshire Coalfield ${ }^{\wedge}$ (Fig. 9.2, Col. 6; Turner 1994). Asturian miospores are also recorded from coals higher in the formation in the South Staffordshire ${ }^{\wedge 5}$ (Fig. 9.2, Col. 5; B. Owens in Old et al. 1991; McNestry 1994), Wyre Forest ${ }^{\wedge}{ }^{2}$ (Fig. 9.2, Col. 4; Owens 1990) and Warwickshire ${ }^{\wedge} 4$ (Fig. 9.2, Col. 6; Butterworth \& Smith 1976) coalfields. However, the presence of macrofloras of the Dicksonites plueckenetii Subzone suggests that the entire Halesowen Formation is of late Asturian age (Cleal 2008). In the type area in South Staffordshire, the formation consists of micaceous sandstone and grey-green mudstone, with thin coals, beds of Spirorbis limestone, conglomerate and caliche. Primary reddening is present locally. The Dark Slade Member (Besly \& Cleal 1997) comprises mostly mudstone and palustrine carbonates with a distinctive geophysical log character in boreholes.

\section{Stephanian}

Red-bed strata of Stephanian age in the region are termed the Salop Formation (Powell et al. 2000b), which comprises the Alveley Member (formerly Keele Member) and overlying Enville Member. The lower member consists predominantly of red mudstone, but the overlying Enville Member has a greater proportion of pebbly sandstone and conglomerate. An Asturian to Cantabrian age is presumed for the Salop Formation, based on comparison with plant fossils in the Oxfordshire coalfields (see Chapter 7) (see discussion in Waters et al. 1995; Besly \& Cleal 1997; Cleal 2008). In the Warwickshire Coalfield, the Salop Formation is subdivided into three members, in upward succession, the Whitacre, Keresley and Allesley members based on the recognition of upwardcoarsening mudstone to sandstone cycles (Bridge et al. 1998).

The highest formation in the Warwickshire Group is preserved only in the Warwickshire Coalfield (Fig. 9.2, Col. 1) where the Tile Hill Mudstone Formation is of probable Cantabrian age. It may range up to Late Autunian (Permian), although no definitive faunas have been found (Shotton 1929; Old et al. 1987; Waters et al. 1995). The uppermost red-bed formations of the Warwickshire Group, such as the Kenilworth Sandstone Formation and Ashow Formation are presumed to be Early Permian in age (Shotton 1929; Bridge et al. 1998; Waters et al. 1995; Powell et al. 2000b).

\section{Figures}

Fig. 9.1. Geological map showing the distribution of Carboniferous strata of the West Midlands to 
Vale of Belvoir adapted from IGS (1979).

Fig. 9.2. Correlation of Carboniferous successions in the West Midlands. The nomenclature is that of Waters et al. (2007; 2009), with details from the following publications: Col. 1 from Pocock et al. (1938); Col. 2 from Bridge \& Hough (2002); Col. 3 from Greig et al. 1968; Col. 4 from Whitehead \& Pocock (1947); Col. 5 from Powell et al. (2000a); Col. 6 from Bridge et al. (1998) \& Powell et al. (2000a); Col. 7 from Worssam \& Old (1988); Col. 8 from Carney et al. (2001); Col. 9 from Carney et al. (2001); Col. 10 from Carney et al. (2004).

Fig. 9.3. Correlation of Westphalian successions in the West Midlands with the nomenclature that of Waters et al. (2007; 2009). a) western part of region, details modified from the following: Shrewsbury- Pocock et al. (1938); Coalbrookdale- Hamblin \& Coppack (1995); Wyre ForestWhitehead \& Pocock (1947); South Staffordshire- Powell et al. (2000a); Cannock Chase- Bridge \& Hough (2002); b) eastern part of region, details modified from the following: Warwickshire- Bridge et al. (1998) \& Powell et al. (2000a); South Derbyshire- Worssam \& Old (1988); North-west Leicestershire- Worssam \& Old (1988); Vale of Belvoir- Carney et al. (2004). 


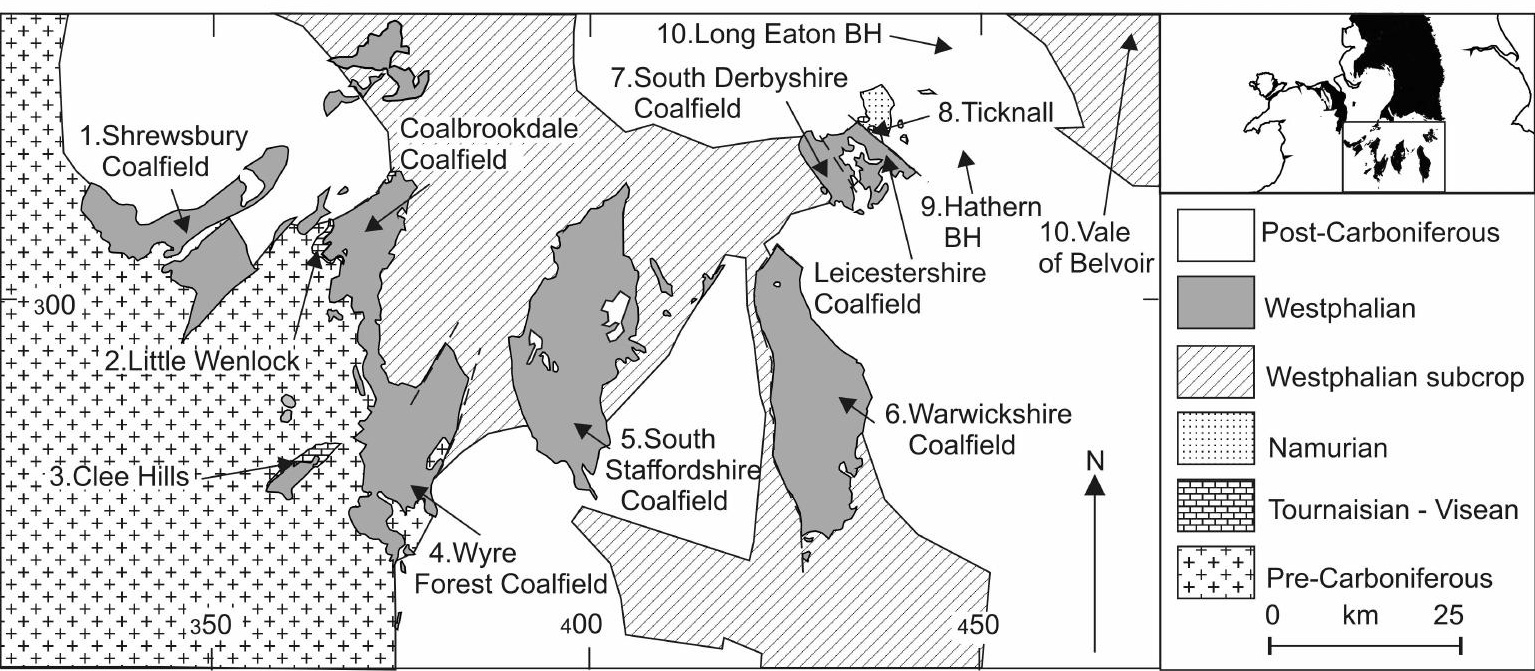




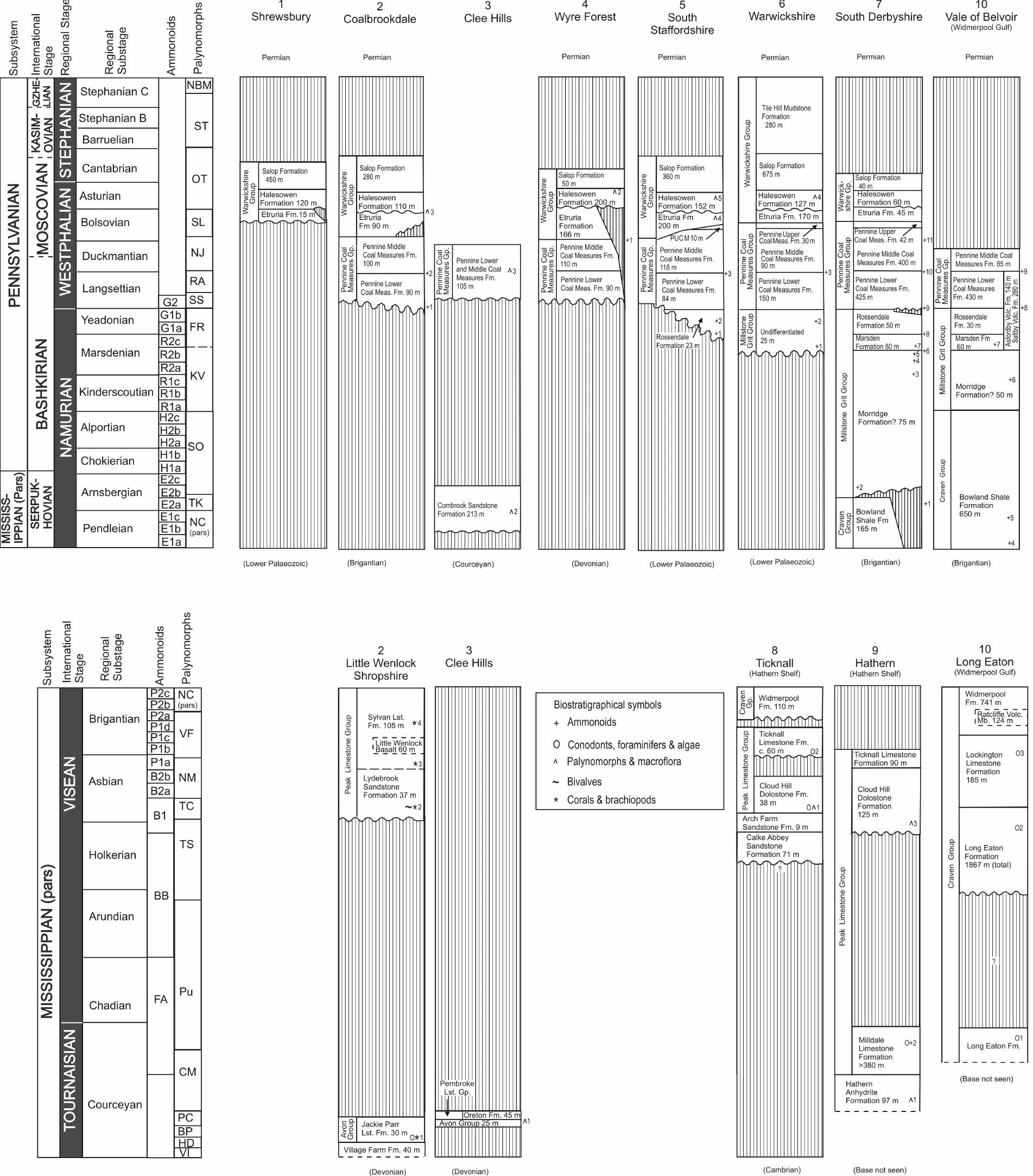




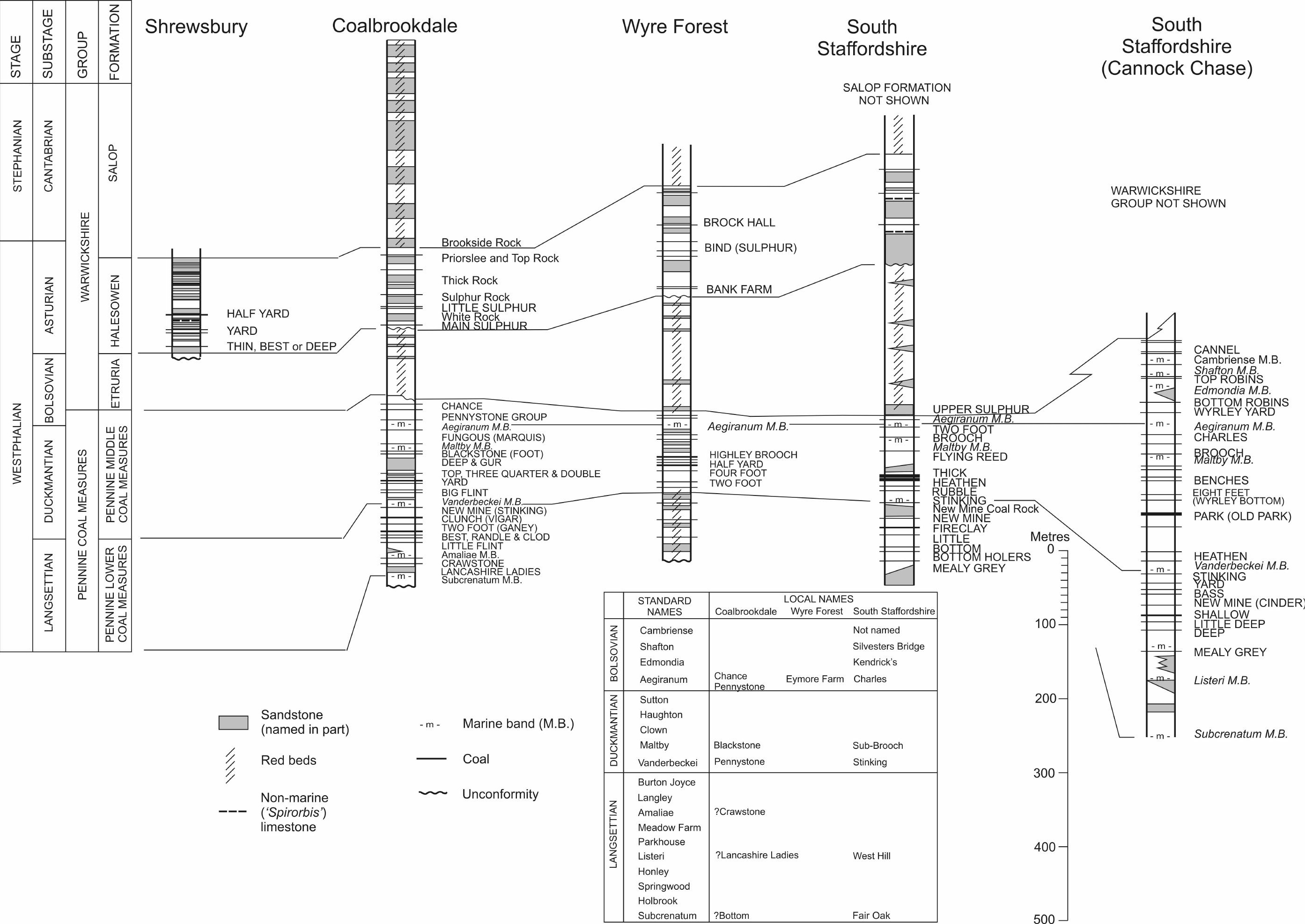




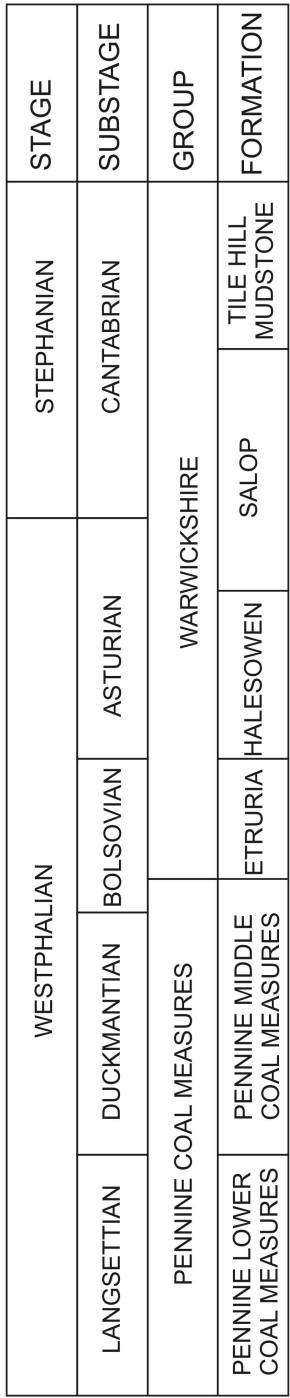

$\left.\begin{array}{lll}x & x \\ x & x & x \\ x & x\end{array}\right]$ Igneous rock

Sandstone

(named in part)

Red beds

Non-marine

('Spirorbis')

limestone
Warwickshire

South Derbyshire

Coalfield

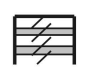

Up to $210 \mathrm{~m}$ not shown

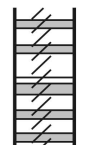

Up to $150 \mathrm{~m}$ not shown
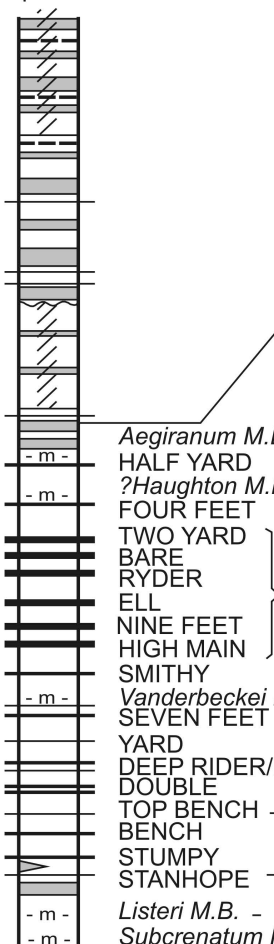

Aegiranum $M$ HALF YARD FOUR FEE TWO YARD ]

BARE LEAVES OF ELL HINE FEET THICK COAL SMHMY

Vanderbeckei M.B.
SEVEN FEET YARD DEEP RIDER/DEEP

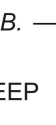

TOP BENCH

STUMPY

Listeri M.B.

Listeri M.B. - - -

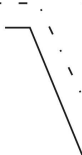

- $\mathrm{m}$ - Marine band (M.B.)

- e - 'Estheria' band

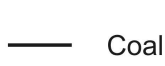

$\sim$ Unconformity

P12 15

Shafton M.B.

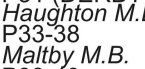

Maltby M.B.

WOODFIELD

STOCKINGS

JOYCE'S
North-west

Leicestershire

Coalfield

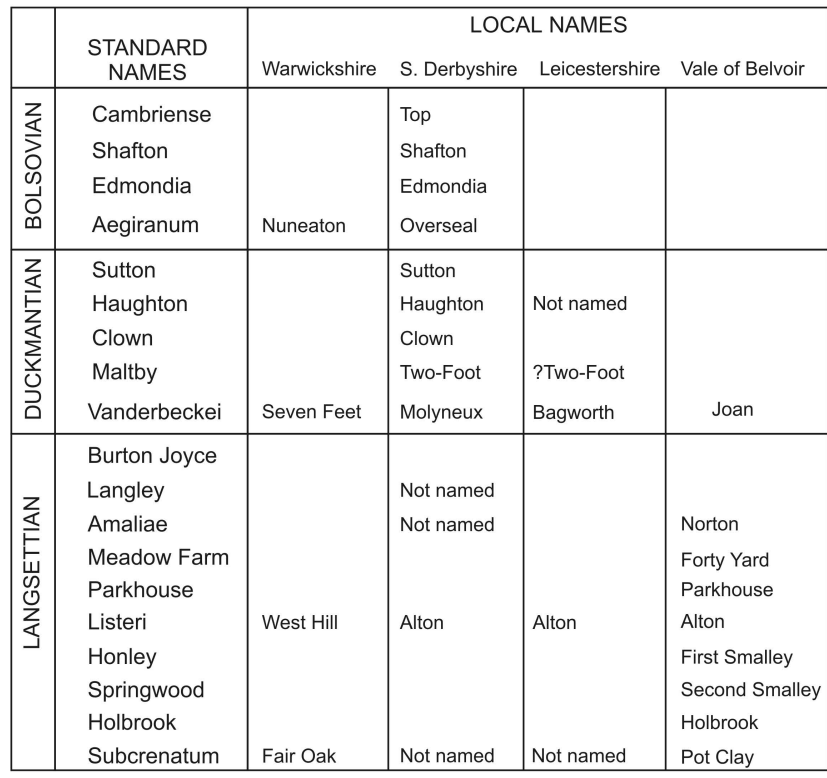

71 ETRURIA FORMATION

P 15 -16 6 .

P20-22 2 M.B.

P23-30 M.B.

A31 (DERBY. B.

Metres

Hill Farm Sandstone

P41-44 $400-$

(DICKY GOBBLER) - -

BLOCK $--c_{-m-1}^{-m}$ ?

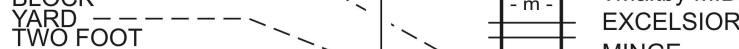

UWO FOOT

FIVE FEET (STONE SMUT)

THREEQUARTERS (SOFT)

NEW MAIN (SLATE)

SWANNINGTON YARD

LITTLE KILBURN (CANNEL) - . -

Vanderbeckei M.B.

Vanderbeckei M.B.

HIGH MAIN

LITTLE WOODFIELD (TOAD)

UPPERMAIN

SMOILELOUNT

MIDDLELOUNT

LOWER MAIN (SLATE)

NETHER LOUNT - . - . .

YARD ---------1

STANHOPE

WELL

CLOD

KILBURN --

KILBURN - - - .

?UPPER BAND

?Listeri M.B. -
ALTON
BELPERLAWN

Vale of Belvoir

Wingfield Flags

Vanderbeckei M.B.

DAN/BROWN RAKE

DEEP MAIN

PARKGATE \& TUPTON ROOF

THPTON NUARTERS

YARD \& YARD FLOOR
BLACKSHALEIASHGATE

MICLEY 1

MICKLEY 4

MICKLEY THIN

KILBURN

Amaliae M.B.

Meadow Farm M.B.
Parkhouse M.B.

Listeri M.B.

Honley M.B.
Springwood M.B.

Holbrook M.B.
H.

Subcrenatum M. B. 